\title{
Mais cuidado com os dados
}

A inda vivemos em um tempo onde os pacientes que nos procuram se entusiasmam e valorizam os equipamentos que ainda não viram em outros consultórios. Investimos em novas tecnologias também por essa razão, mas fundamentalmente para melhorar a assistência à população. Alguns exemplos de aparelhos que "nunca se pagam", mas que melhoram muito nossa pràtica, incluem os campímetros visuais computadorizados e os Yag Laser. Nem por isso deixamos de adquirir os equipamentos e indicar os exames e procedimentos.

Temos certa clareza e ampla discussão ao requisitar e realizar novos exames, mas ainda temos espaço para potencializar o uso desses modernos equipamentos.

A informática foi a grande responsável pela atualização de aparelhos que mantém em grande parte a base física de sua origem. Os tomógrafos de segmento anterior derivam diretamente da lâmpada de fenda, só que ganharam enorme poder com a digitalização de imagens e posterior análise quantitativa.

A digitalização de dados é a base da nossa moderna propedêutica, e indica que temos tabelas com números e fórmulas capazes de refazer o exame mesmo na ausência dos pacientes. Tal potencialidade permite reduzir o espaço físico para o arquivamento dos exames e comparar exames realizados em tempos distintos.

Em áreas como o glaucoma, a avaliação temporal do nervo óptico determina o tratamento do paciente. Na cirurgia refrativa, topografias corneanas sequenciais determinam se o paciente tem ceratocone ou não. $\mathrm{O}$ mesmo ocorre em retinopatias, tumores, etc.

Infelizmente tal potencialidade não é utilizada em sua plenitude, pela simples razão que não temos suporte técnico e nem conhecimento suficiente para guardar os dados de modo adequado.

Hoje temos o menor custo de armazenamento de dados da história, e as soluções passam por servidores sem fio com sincronismo automático, como vemos no "time machine" da empresa americana Apple.

A simplicidade porém não é suficiente para que tenhamos os dados organizados e disponíveis de modo seguro, por longo tempo. Ameaças como os vírus causam perda de dados pela falta de copias de segurança. Reinstalações de sistemas operacionais dos aparelhos e dos computadores causam as mesmas perdas. Problemas com mídias de armazenamento também são fontes de problemas. Acabamos tendo muito menos informação e poder de decisão do que poderíamos ter.

A solução passa pela conscientização da importância dos dados dos pacientes dos quais somos, perante a lei, depositários. Após a conscientização, precisamos demandar dos distribuidores, a efeti- 
va, correta e contínua assistência técnica dos dados, instalando, mantendo e modernizando os servidores, cópias etc.

Desse modo estaremos oferecendo melhores serviços, com os mesmos aparelhos disponíveis, e poderemos continuar valorizando e aumentando o valor de nossa prática diária.

Paulo Schor Livre-docente, Professor Adjunto do Departamento de Oftalmologia da Universidade Federal de São Paulo 